\title{
A METHOD FOR ASSESSING THE CONDITIONS OF MIGRATION OF POLLUTANTS TO THE GROUNDWATER ON THE AGRICULTURALLY USED LOWLAND AREAS
}

\section{THE PURPOSE AND THE SCOPE OF THE STUDY}

The paper presents the method of classifying the territory of an agricultural lowland catchment in terms of conditions for migration of pollution into the groundwater. The method allows for the determination of the areas little threatened with rapid migration of pollutants, and thus indicates the locations appropriate for, in particular, water-related investment projects (like location of uptakes of groundwater resources). The method can be used in other catchment areas of similar nature (lowland agricultural basins).

Achievement of the optimum effect of classification requires having the following research tasks resolved:

- Selection of the appropriate, physically justified diagnostic variables, which describe in the best way the process of migration of pollution in the aeration zone, and their identification.

- Selection of the appropriate method of determination of the basic study unit (the quasi-homogeneous field).

- Separation of the spatial classes.

- Substance-matter-based interpretation of the results of classification and their verification.

\section{THE OBJECT OF STUDY}

The study was carried out in the upper part of the Wilga river basin (a right-hand confluent of Vistula). The surface area of this part of the basin is $231.6 \mathrm{sq} . \mathrm{km}$. The hydrometric profile, which closes out the catchment area considered is situated in the locality of Oziemkówka (Fig. 1). The area is typically agricultural, with an only marginal share of industry in the economy. The results of analyses of the air, and of the chemical composition of water, indicate that the quality of groundwater within the catchment area is mostly influenced by farming. 


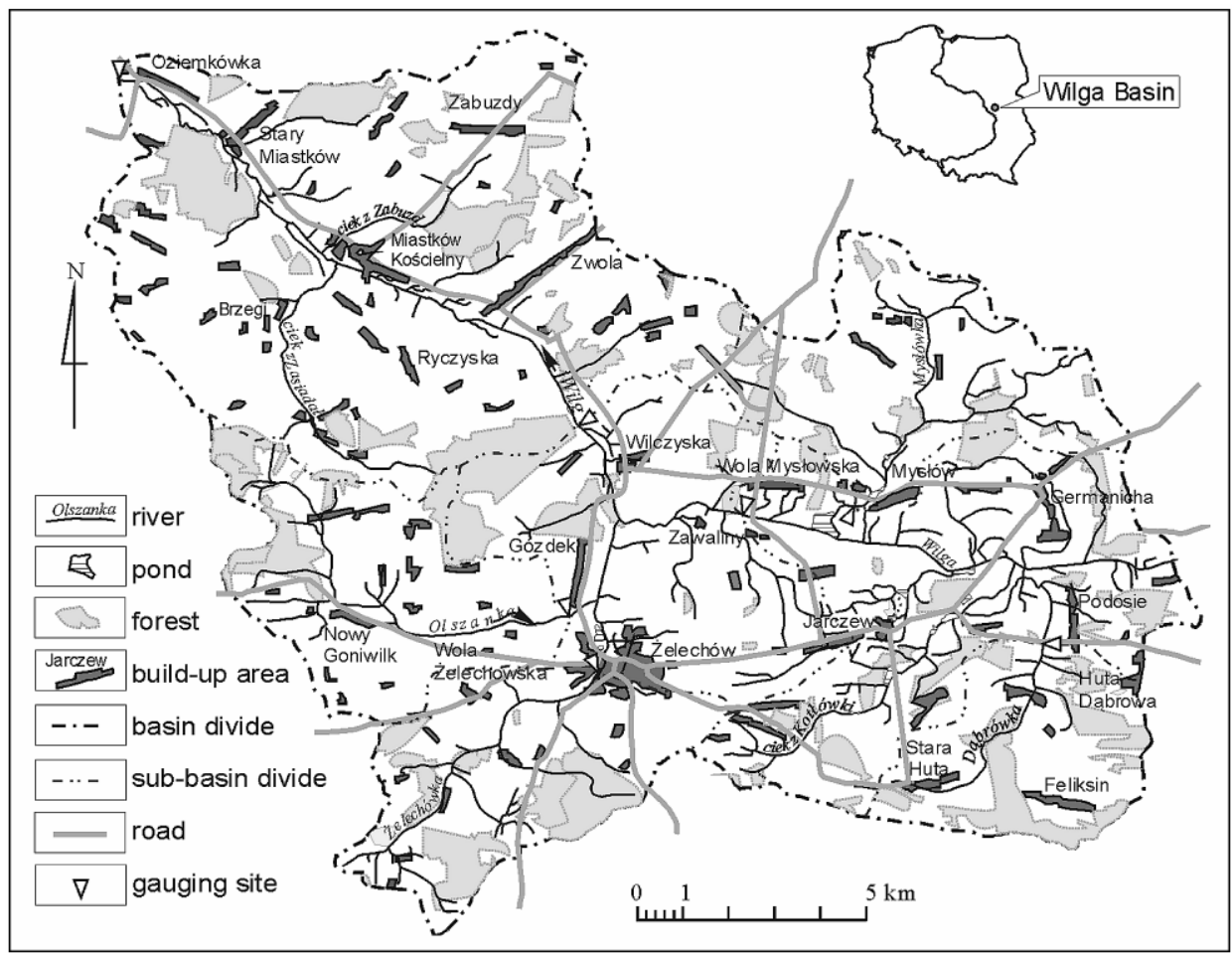

Fig. 1. The upper part of Wilga river basin.

\section{SELECTION OF THE DIAGNOSTIC VARIABLES}

There are many factors, which contribute to the susceptibility of the aquifers to pollution. They include hydrogeological conditions and the nature of polluting substances. Consideration of all the factors is extremely difficult, and, in addition, several parameters are very poorly known. Each of the polluting substances may in definite hydrogeological conditions migrate in a different manner. There is no single joint parameter, which would characterise migration capacities of a range of chemical compounds at the same time, and so in the majority of assessments it is assumed that pollution moves approximately in the same way as the particles of water do (Błaszczyk and Górski, 1992). Such an assumption was also made in the here presented study.

In the choice of the diagnostic variables with respect to the problem analysed use was made of the existing methods and models, and in particular, of the solutions elaborated and applied by the institutions dealing with environmental protection in the world and in Poland. Likewise, equations were analysed meant to describe the process of transport of humidity and pollution in the aeration zone (Kowalik, 1999; Szulczewski, 1990). 
Consequently, it was assumed that the conditions for migration of pollution to the groundwater can be characterised with the following diagnostic variables: the coefficient of hydraulic conductivity, the field capacity of soils, the permanent wilting point (of plants), the thickness of the aeration zone, the maximum reach of the root zone, and the slope.

\section{IDENTIFICATION OF THE DIAGNOSTIC VARIABLES}

Coefficient of hydraulic conductivity of the granular substances, such as, in particular, various kinds of sand, were calculated with the "American formula" (USBSC) (see Pazdro and Kozerski, 1990). The compact formations (clays, loams) constitute as a rule a barrier to the infiltrating water. That is why it was considered admissible to adopt for purposes of the here presented study the values of the filtration coefficients cited in the literature available.

The reserve of water in the upper parts of the soil profiles, for humidity corresponding to the of permanent wilting point and the field capacity was calculated using the dependencies proposed by Somorowski (1967). This author demonstrated that the field capacity and the permanent wilting point can be estimated with sufficient precision on the basis of the mechanical composition of soils, and in particular - the contents of the washable parts and of the organic matter. In calculation of the filtration coefficients and the reserves of water in the soil for the permanent wilting point and the field capacity use was made of the study material accumulated at the Institute of Meteorology and Water Management in Warsaw. The variables were presented in the form of digital dot maps.

Depth of the root zone of the plant associations in the basin of upper Wilga was estimated on the basis of topographical maps on the scale of $1: 25,000$, aerial photography (scale of about $1: 18,000$ ) and own field studies. This was the foundation for the elaboration of the numerical grid map of land use in the basin. The land use forms within the study area were associated with a database (table of attributes of the grid map), containing information on the depth of root zone. The respective values were adopted on the basis of results of study of various authors, as well as own field observations.

Thickness of the aeration zone was read out of the digital map of the hydroisobats. The map was elaborated using the data from 23 wells observed in the years 1974-1991, and representing the surface-adjacent aquifer level of the basin (Fig. 2). The number of points for spatial interpolation was increased by introducing into the base the information on location of flows and ponds in the upper part of Wilga river basin and its vicinity (acquired through digitalisation of the river network on the basis of topographical maps). In addition, synthetic points were accounted for obtained from the analysis of the results of measurements of the underground water levels, carried out on 27-28 December 1999 and 31 March - 1 April 2000. Among the available procedures of automatic interpolation methods the one of inverse distances was used with exponent 2. 


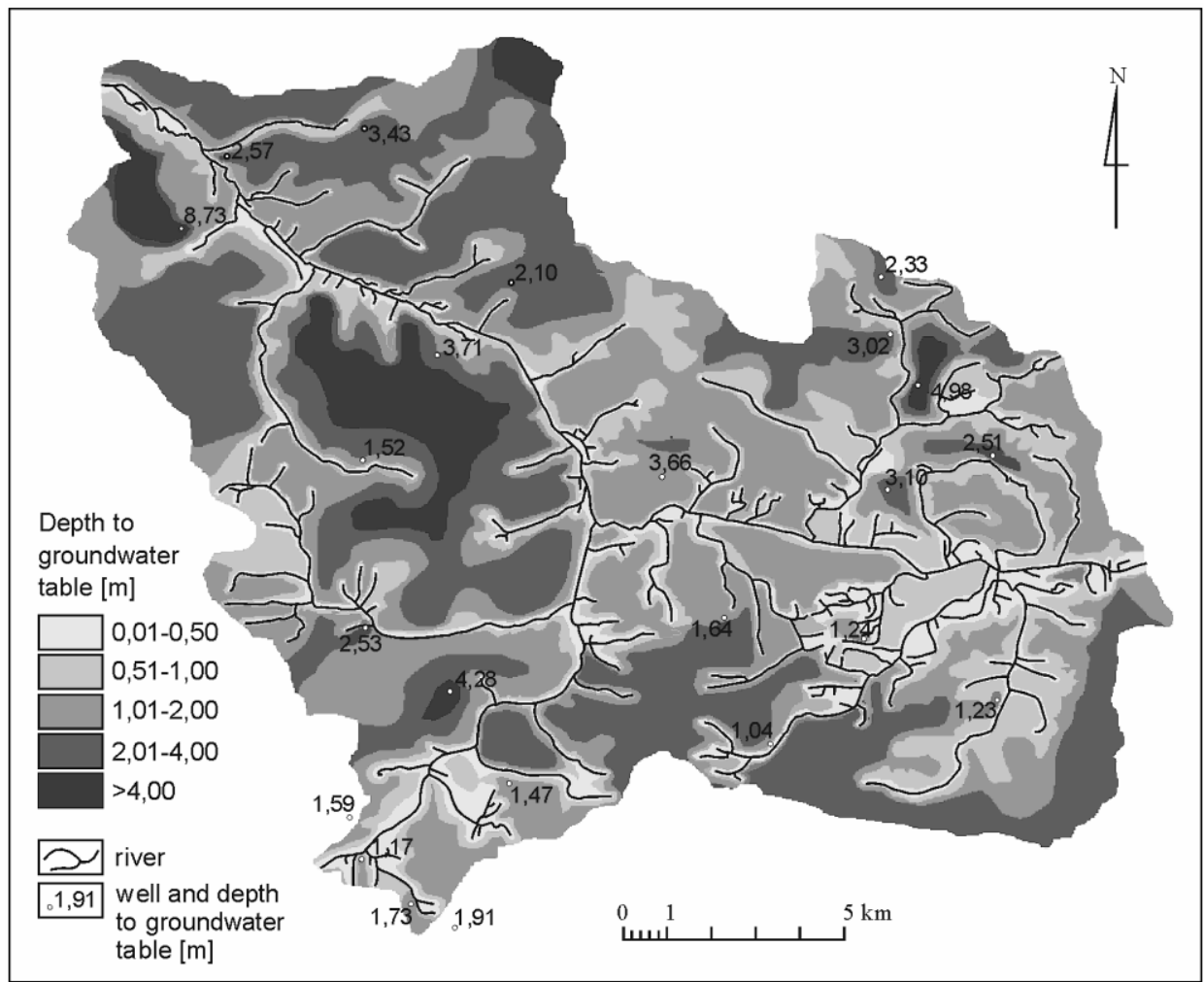

Fig. 2. Mean groundwater table depth in Wilga river basin in the years 1974-1991.

The basis for elaboration of the map of slopes (relief gradients) in the basin of upper Wilga river was constituted by the numerical model of relief, prepared in the Department of Hydrology of the University of Warsaw (Fig. 3). For purposes of the present study, after having introduced corrections, the procedure of interpolation was repeated, and the numerical model of relief was developed, on whose basis the numerical map of slopes was prepared.

The numerical maps of hydroisobats, land use (depth of the root zone), and slopes, were elaborated as grid maps, with spatial resolution of $25 \mathrm{~m}$. Adoption of this resolution level resulted from the precision of the source materials and the potential errors arising during the process of digitalisation of maps and aerial photography (Magnuszewski, 1999).

\section{ESTABLISHMENT OF THE DIMENSIONS OF QUASI-HOMOGENOUS FIELDS AND IDENTIFICATION OF DIAGNOSTIC VARIABLES WITHIN THEM}

The dimensions of the elementary unit fields were determined by applying two methods. Resulting from the first method, which assumed dependence 


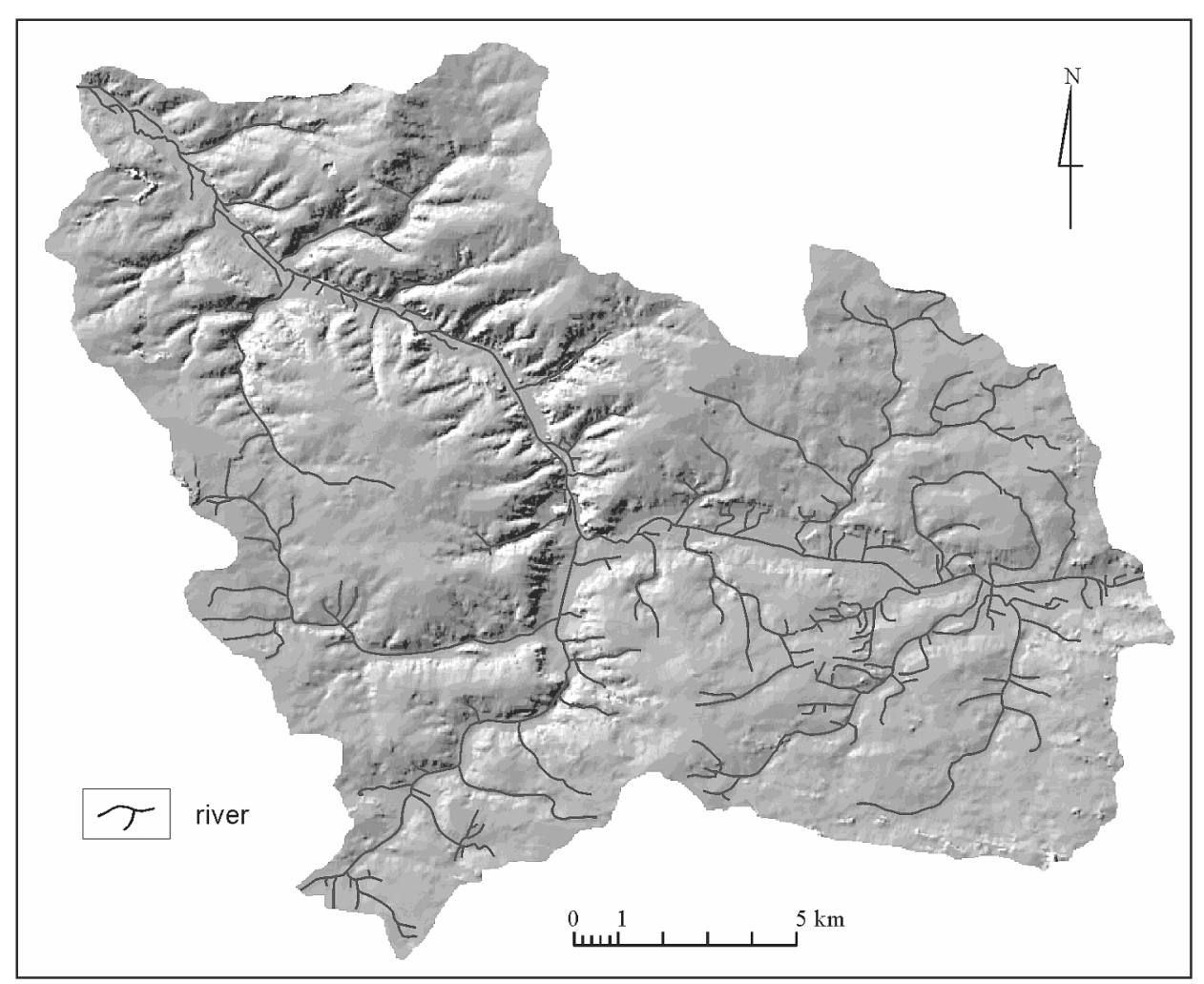

Fig. 3. Digital terrain model of the Wilga river basin.

of the magnitude of the quasi-homogeneous unit on the magnitude of the entire area studied (the geometric method), division into 274 square fields with sides of $1 \mathrm{~km}$ of length was obtained (Suchożebrski, 2001). This division was obtained by overlaying the kilometre grid on the topographic map on the scale of $1: 25,000$. The diagnostic variables identified within the quasihomogeneous fields established with the geometric method were ordered in the information matrix $M_{1}\{n \times m\}$, where $n=256$ observations (quasihomogeneous fields) and $m=6$ spatial features (diagnostic variables).

In the second method the dimensions of the basic field are made dependent upon the spatial differentiation of the diagnostic variables. The systematic variability of the data (the diagnostic variables) was determined with the use of the geostatical methods (Suchożebrski, 2001). One of these methods is semi-variance, with semi-variogram as the basis (Goovaerts, 1998). It is assumed in the semi-variance method that correlation between measurement points decreases with distance and disappears after a certain limit distance, called radius of influence, is exceeded. The value of the radius of influence may constitute the determinant of the dimensions of the elementary field. Adoption of the side of the field smaller than the value of the radius of 
influence allows for preservation of a high level of uniformity of the data within the cell of the grid, and at the same time makes it possible to represent the actual variability of the phenomenon over the entire area.

The original semi-variograms and their models were elaborated on the basis of digital maps of the depth of groundwater (the map of hydroisobats), of the depth of the root zone, and of the surface gradients (slopes). In the case of diagnostic variables presented in the form of dot maps (filtration coefficients and reserves of water in the upper layer of soil, corresponding to the permanent wilting point and the water capacity) the nearest neighbour algorithm was used for optimisation of the dimensions of the elementary (quasi-homogenous) field.

The semi-variance analysis and the nearest-neighbour analysis, carried out on the basis of digital maps, indicate that in view of the differentiation of the natural environment in the basin it is not possible to adopt the same magnitude of the basic field for all the diagnostic variables. It is admissible, though, to apply different dimensions of the grid cell depending upon the spatial differentiation of the diagnostic variables (Pokojska, 2000). The basic dimension assumed was the square field with the side of $0.6 \mathrm{~km}$, corresponding to the spatial differentiation of the slopes (gradients) and the depth of the root zone (Suchożebrski, 2001). This length is contained between 1/5 and $1 / 3$ of the radius of influence, determined on the basis of analysis of the semi-variograms. The depth to the groundwater was identified for the square fields $1.2 \mathrm{~km} \times 1.2 \mathrm{~km}$, composed of four fields having the sides of $0.6 \mathrm{~km}$. In these cases, when no point existed within a cell of such a grid, the variables were identified in the field with $1.2 \mathrm{~km}$ side, and then - with $2.4 \mathrm{~km}$ side (16 fields with $0.6 \mathrm{~km}$ side). Application of variable magnitude of the cells forming the grid of the quasi-homogenous fields guarantees that at least one point (soil profile) will be located in each of them. Such fields were then divided into the smaller ones, so that ultimately the grid of 647 square quasiuniform fields with the side of $0.6 \mathrm{~km}$ was obtained.

The diagnostic variables identified in the quasi-homogenous fields established with the use of the geostatical methods were ordered in the form of the matrix of spatial information $M_{2}\{n \times m\}$, where $n=647$ elementary fields with the side of $0.6 \mathrm{~km}$, and $m=6$ diagnostic variables.

\section{REDUCTION OF THE INFORMATION MATRIX}

The matrices of spatial information $M_{1}$ and $M_{2}$ were reduced using principal component analysis. The procedure carried out was also aimed at getting rid of the correlation between the diagnostic variables. Owing to the application of the principal component analysis the set of the original six diagnostic variables was in both cases replaced by the three synthetic variables, not correlated among themselves. These principal components were: the absorption conditions indicator (linking the filtration coefficient, the in-field water capacity, and the humidity of permanent withering), the infiltration 
path indicator (related to the depth of the underground water and the thickness of the root zone), and the relief gradient (slope) indicator.

\section{GROUPING OF FIELDS UNIFORM WITH RESPECT TO CONDITIONS OF MIGRATION OF POLLUTANTS TO THE GROUNDWATER}

The grouping of the quasi-homogenous fields (distinguished with both methods) with respect to the conditions of migration of pollutants into the groundwater was performed with the use of the methods of numerical taxonomy. Resulting from classification, carried out with the Ward algorithm, there were four types (typological classes) of conditions of migration of pollutants to the groundwater. These classes correspond to the conditions, which are: the least advantageous (type A), the average (type B), the advantageous (type $\mathrm{C}$ ), and the very advantageous (type D), for migration of pollutants to the groundwater.

The maps illustrating the results of classification clearly show the dichotomous character of the catchment area (Fig. 4). Thus, in the western part the quasi-homogenous fields dominate, in which the least advantageous and advantageous (types $\mathrm{A}$ and $\mathrm{C}$ ) conditions for migration of pollutants to groundwater were identified. In the eastern part the average and the very advantageous conditions for migration of pollutants to the groundwater (types B and D) dominate. This division results from the different conditions in the natural environment, expressed first of all through the bigger share in the western part of the basin considered occupied by the areas with steeper slopes, deeper ground water levels, and presence of clayey formations in the bedding.

\section{VERIFICATION OF THE SPATIAL UNITS DISTINGUISHED}

The method was verified by carrying out the comparison of the maps obtained showing the conditions of migration of pollutants to groundwater with the measurements of selected chemical parameters of these waters. For this purpose, water samples were taken and respective measurements made on three time instants: 28-29 December 1999, 31 March - 1 April 2000, and 23-24 August 2000. The tests of the MERCK company (Aquamerck) were used to designate the contents of ions of $\mathrm{NH}_{4}{ }^{+}, \mathrm{NO}_{2}^{-}, \mathrm{NO}_{3}^{-}, \mathrm{PO}_{4}^{-}, \mathrm{Cl}^{-}$, the total hardness, and additionally the level of $\mathrm{pH}$, as well as (in some of the samples) the contents of $\mathrm{SO}_{4}{ }^{-}$.

The measurements of the chemical properties of groundwater indicate that the results of classification of fields determined with the use of the geostatical methods are more correct (closer to the actual pollution levels). The highest agreement was obtained in the comparison of the maps presenting the conditions of migration of pollutants to groundwater with the results of measurements of phosphates $\left(\mathrm{PO}_{4}{ }^{-}\right)$. The agreement was decidedly lower for the 


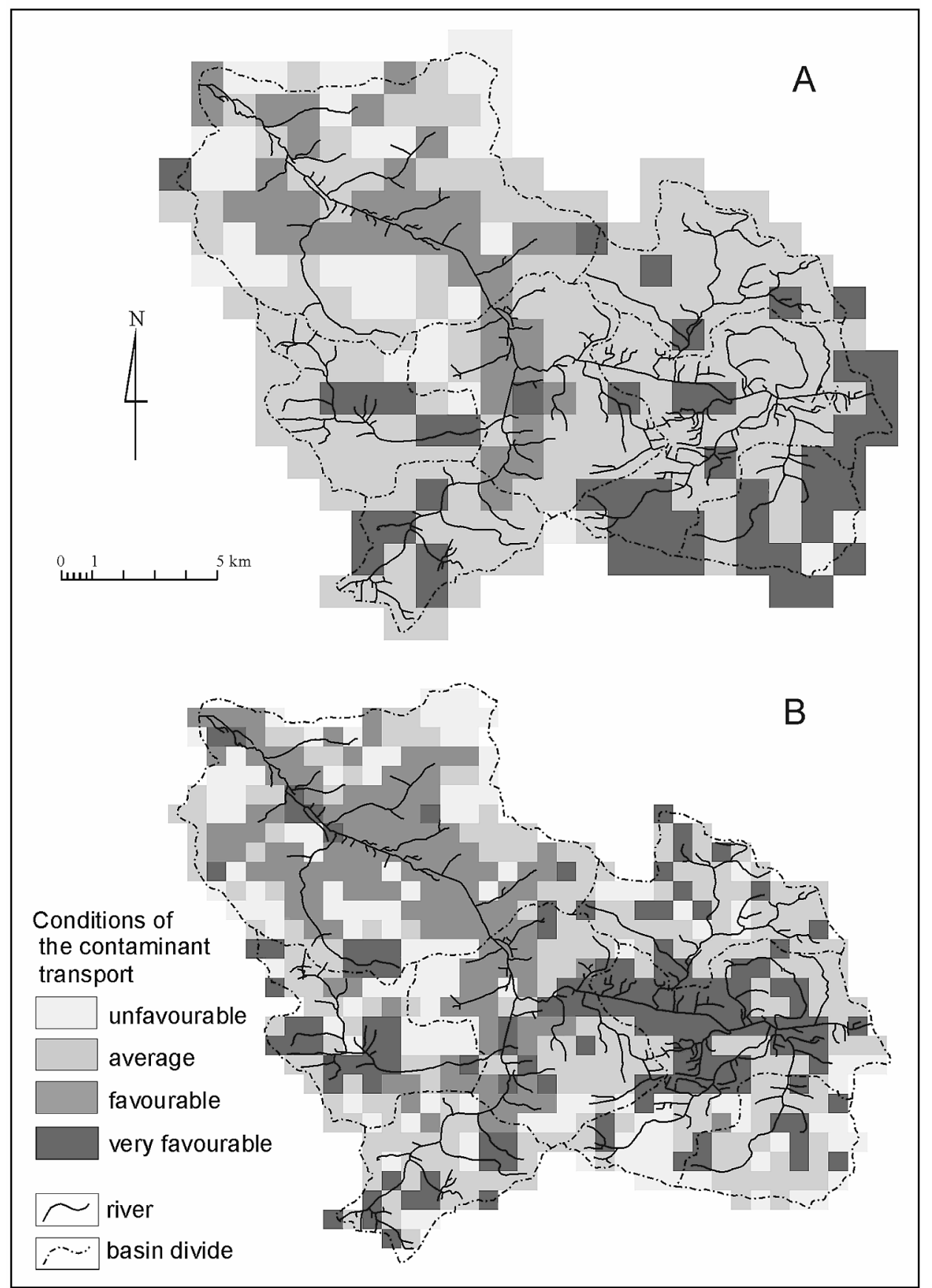

Fig. 4. Conditions of the contaminants transport to groundwater in the Wilga river basin; the classification of basic units, which are delimited by geometrical method (A) and geostatistical methods (B). 
measurements of nitrates $\left(\mathrm{NO}_{3}{ }^{-}\right)$. Disagreement was observed for the results of classification and the measurements of the contents of ammonia, nitrites, sulphates, chlorides, and the total hardness of water. These disagreements result mainly from the local pollution of groundwater. The pollutants in question are the organic ones, being primarily the effects of the influence of the leaking settling tanks (or their lack altogether), improper storage of manure, as well as inadequate management of other waste resulting from livestock husbandry.

\section{CONCLUSIONS AND SUMMARY}

- The method presented makes it possible to characterise with sufficient precision the conditions for migration of pollutants to the groundwater in the agricultural lowland catchment areas, and then to show them on the maps.

- The basic fields, being the foundation of classification, may take on the form of a grid of regular quasi-homogenous fields. Application of the block model allows for an easier identification of parameters and assignment of the point values to larger areas, as well as a good approximation of the spatial distribution of the parameters of the catchment area considered.

- Application of the geostatical methods for the determination of the magnitude of the cells forming the grid of quasi-uniform fields makes it possible to account for the differentiation of the natural environment conditions and for the density of the measurement points.

- The geometric method of establishing the magnitude of the cell of the grid of elementary fields can be used in large basins, where the analyses and the results are characterised by a higher degree of generalisation.

- The methods of numerical taxonomy can be used effectively for classification. Among the available methods of cluster analysis the best results were obtained when the quasi-uniform fields were grouped with the use of the Ward algorithm.

- In the grouping of the quasi-homogeneous fields established with the use of the geometric method and the geostatical methods, the division into four typological classes was considered optimal. These classes correspond to: (type A) the least advantageous, (type B) the average, (type C) the advantageous, and (type D) the very advantageous conditions for migration of pollution to underground water.

- The measurements of the chemical properties of the groundwater show that the results of classification of the fields determined with the use of the geostatical methods are more correct (in terms of agreement with the actual pollution). The highest degree of agreement was obtained by comparing the maps of migration conditions for the pollutants penetrating into the groundwater with the results of measurements of the phosphates $\left(\mathrm{PO}_{4}{ }^{-}\right)$.

- The Geographical Information Systems (GIS) facilitate significantly and accelerate identification of the diagnostic variables, as well as elaboration of the output maps. The database on the natural environment of the catchment 
area considered, established with the help of the GIS, may be used for other purposes.

- The maps elaborated can constitute the basis for planning of uptake of groundwater and for delimitation of the protective zones around them. They also enable indication of the locations, where chemical compounds contained in the fertilisers might easily penetrate into the aquifers.

\section{REFERENCES}

Błaszczyk T., Górski J., 1993, Zanieczyszczenie, zagrożenie i ochrona wód podziemnych $w$ Polsce [Pollution, hazards, and protection of the groundwater in Poland; in Polish], Wyd. Nauk. UAM, Poznań.

Goovaerts P., 1998, Geostatistical tools for characterising the spatial variability of microbiological and physico-chemical soil properties, Biol. Fertil. Soils, vol. 27.

Kowalik P., 1999, Ochrona środowiska glebowego [Protection of the soil environment; in Polish], Wyd. Politechn. Gdańskiej, Gdańsk.

Magnuszewski A., 1999, GIS $w$ geografii fizycznej [The GIS in physical geography; in Polish], Wyd. Nauk. PWN, Warszawa.

Pazdro Z., Kozerski B., 1990, Hydrogeologia ogólna [General hydrogeology; in Polish], Wyd. Geol., Warszawa.

Pokojska P., 2000, Model hydrologiczny o parametrach przestrzennie rozłożonych, integrowany z Systemem Informacji Geograficznej [Hydrological model with spatially distributed parameters, integrated with the Geographical Information System; in Polish], Przegl. Geofiz., vol. 45, 3-4.

Somorowski Cz., 1967, Obliczanie dawek polewowych nawodnień deszczownianych na podstawie właściwości wodnych profilu glebowego [Calculation of the irrigation doses of sprinkler irrigation on the basis of the hydrological properties of the soil profile; in Polish], Gosp. Wodna, No. 6.

Suchożebrski J., 2001, Obiektywne metody określania rozmiaru pola podstawowego w badaniach hydrologicznych [Objective methods of determination of the basic field in hydrological studies; in Polish], Przegl. Geofiz., vol. 46, 1-2.

Szulczewski W., 1990, Modelowanie rozprzestrzeniania zanieczyszczeń chemicznych oparte na liniowym równaniu dyspersji [Modelling of the transport of chemical pollutants based on the linear dispersion equation; in Polish], Zesz. Nauk. Akad. Roln. we Wroctawiu. Melioracja, No. 192. 